\title{
First report of Konjac mosaic virus in elephant foot yam (Amorphophallus paeoniifolius) from India
}

\author{
M. Padmavathi • K. P. Srinivas • M. Hema • P. Sreenivasulu
}

Received: 1 August 2012 / Accepted: 7 December 2012 /Published online: 22 December 2012

(C) Australasian Plant Pathology Society Inc. 2012

\begin{abstract}
Natural association of Konjac mosaic virus (KoMV) with mosaic disease of elephant foot yam (Amorphophallus paeoniifolius) in India was identified by enzyme-linked immunosorbent assay using an antiserum raised against KoMV recombinant coat protein (CP) and immunocapture-reverse transcription-polymerase chain reaction using CP gene specific primers. Sequence analysis showed 77.2-98.9\% and 92.1-98.2\% identities at CP nucleotide and amino acid levels, respectively with the reported KoMV isolates.
\end{abstract}

Keywords Elephant foot yam · Mosaic · IC-RT-PCR ·

Konjac mosaic virus

Amorphophallus paeoniifolius (syn: A. campanulatus, elephant foot yam) is one of the important aroid tuber vegetable crops cultivated for its corms in tropical and sub-tropical regions of Asia (Ravi et al. 2009). This crop is mainly propagated through vegetative propagules (corms) and so any virus infecting the crop has quarantine relevance as the virus is vertically transmitted. Thus correct identification of viruses transmitted through vegetative propagules has significance. So far, Dasheen mosaic virus (DsMV) in India and Konjac mosaic virus (KoMV) in Japan have been reported to naturally infect Amorphophallus species (Shimoyama et al. 1992; Pandit et al. 2001; Babu et al. 2012). Recently, partial genome sequence of a potyvirus associated with infections on elephant foot yam in Kerala, India confirmed the virus as DsMV (Genbank A/C HQ207537). Nishiguchi et al. (2006) have determined the full-length genome sequence of KoMV-F isolate and confirmed its

M. Padmavathi $\cdot$ K. P. Srinivas $\cdot$ M. Hema $(\bowtie) \cdot$ P. Sreenivasulu Department of Virology, Sri Venkateswara University,

Tirupati 517502 Andhra Pradesh, India

e-mail: hemamasarapu70@gmail.com identity as a distinct virus species in the genus Potyvirus, family Potyviridae. Further, they have suggested that Zantedeschia mosaic virus, previously identified as a new potyvirus (Kwon et al. 2002) based on partial genome sequence analysis, is now considered as a strain of KoMV. Padmavathi et al. (2011) have determined the partial genome sequence from $3^{\prime}$ end $(\sim 1.6 \mathrm{kbp})$ of three potyvirus isolates and identified for the first time the association of KoMV with infections on Colocasia, Caladium and Dieffenbachia spp. from Andhra Pradesh, India.

In India, elephant foot yam is extensively cultivated in Andhra Pradesh, West Bengal, Gujarat, Kerala, Tamil Nadu, Maharastra, Uttar Pradesh and Jarkhand states (Ravi et al. 2009). Elephant foot yam showing initially prominent chlorotic spots followed by chlorotic vein banding and mosaic symptoms were observed in Andhra Pradesh during commercial field surveys in 2011 (Fig. 1). Symptomatic leaf samples (26) collected from different locations in Andhra Pradesh tested positive ( $\mathrm{A}_{405}$ values: infected - 0.94-1.35, healthy - 0.13-0.15) for KoMV by DAC-ELISA (Clark and Bar-Joseph 1984) using polyclonal antibodies produced to recombinant coat protein ( $\mathrm{rCP}$ ) of $\mathrm{KoMV-Col-AP}$ isolate infecting taro (Padmavathi 2012). IC-RT-PCR was performed by the procedure of Nolasco et al. (1993) for amplification of CP gene from symptomatic Amorphophallus leaves using rCP KoMV-Col-AP antibodies and CP specific primers of KoMV-Col-AP isolate (KoMV-Col-CP-F - 5' CAAGGGATCCAGTGGAGAGGAAGA GAAG 3; KoMVCol-CP-R-5'CTGAGAATTCCTAAATAGCGCGCACAC $3^{\prime}$ ), and it yielded an amplicon of the expected size of 849 nucleotides (Fig. 2). The CP amplicon was cloned into pTZ57/RT vector (Fermentas, USA), sequenced and deposited in GenBank DNA database (Accession No. JQ773440). Sequence analysis (BioEdit v. 7.0.5) and comparison with reported KoMV isolates showed 77.2-98.9\% and 92.1-98.2\% identities at CP gene nucleotide and amino 
Fig. 1 a Healthy elephant foot yam. b Elephant foot yam leaves showing chlorotic vein banding and mosaic symptoms
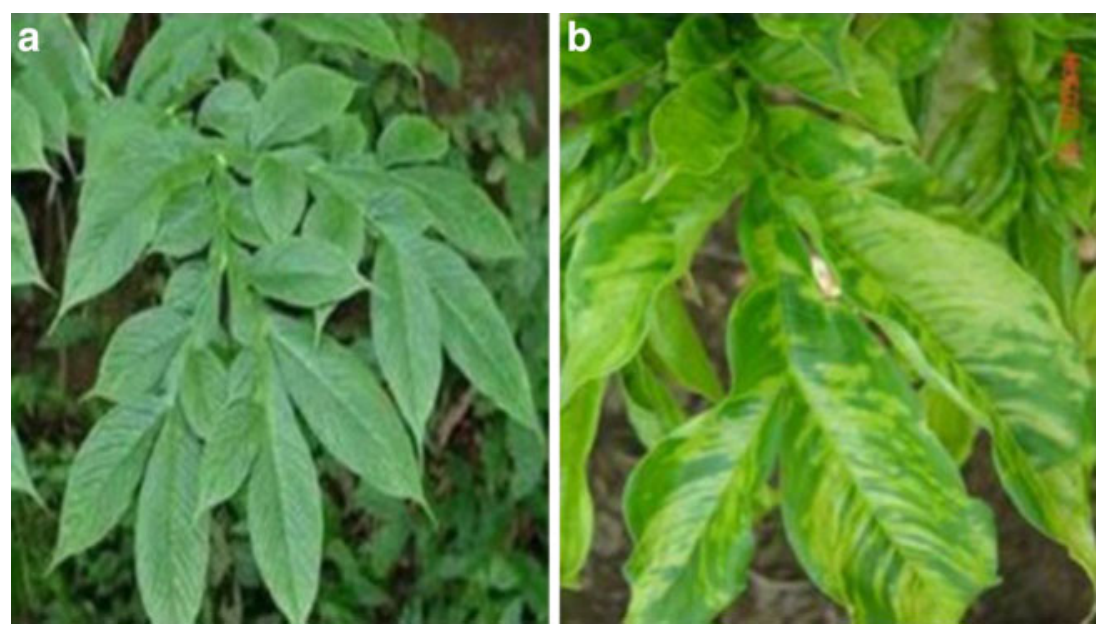

acid levels, respectively. The present virus isolate $\mathrm{CP}$ has DAG triplet in its N-terminus like several other aphidtransmitted potyviruses, The other conserved motifs identified in the CP are WCIEN, AFDF, RQ, RAREA, QMKA, LDG and TERHT (Adams et al. 2005). Phylogenetic relationships with other potyviruses infecting aroid plants were determined based on deduced coat protein amino acid sequence and the present virus isolate clustered with KoMV isolates recently reported from Andhra Pradesh, India (Fig. 3; Padmavathi et al. 2011).

Based on the molecular criteria suggested for discrimination of unknown potyvirus isolates (Adams et al. 2005), the present virus isolate associated with cholorotic spots, chlorotic vein banding and mosaic symptoms on $A$. paeoniifolius in Andhra Pradesh, India was identified

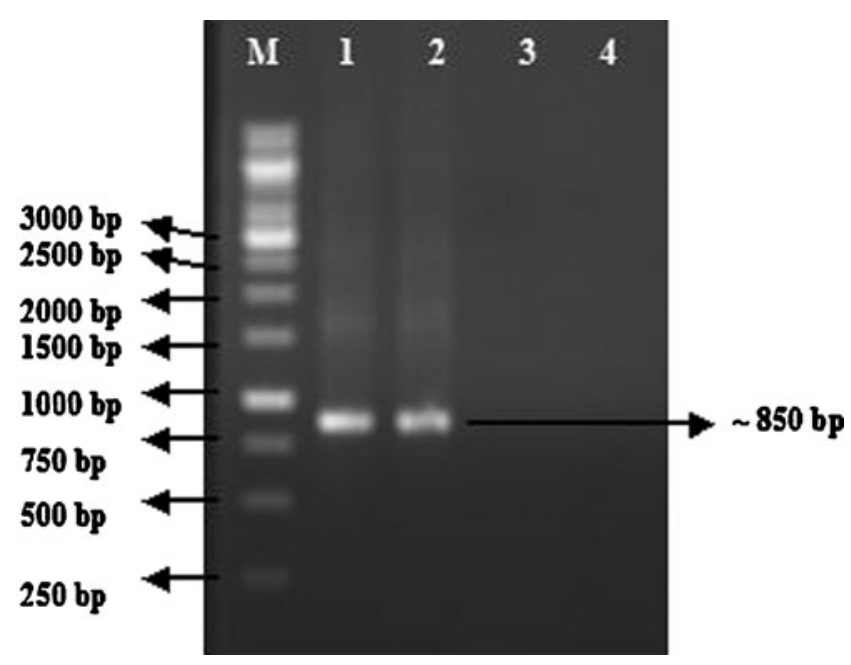

Fig. 2 IC-RT-PCR amplification of KoMV-Amor-Chi-AP isolate coat protein $(\mathrm{CP})$ gene using KoMV CP specific primers. Lane M, Gene Ruler $1 \mathrm{~Kb}$ DNA ladder (Fermentas, Canada). Lane 1, 2, Amorphophallus leaves with mosaic symptoms. Lane 3, 4, healthy Amorphophallus leaves for the first time as a strain of KoMV and we named it as KoMV-Amor-Chi-AP. This is the second potyvirus naturally associated with $A$. paeoniifolius in India. This work can help to design multiplex diagnostic methods for parallel screening and differentiation of potyviruses associated with elephant foot yam germ plasm and mother plants meant for micropropagation.

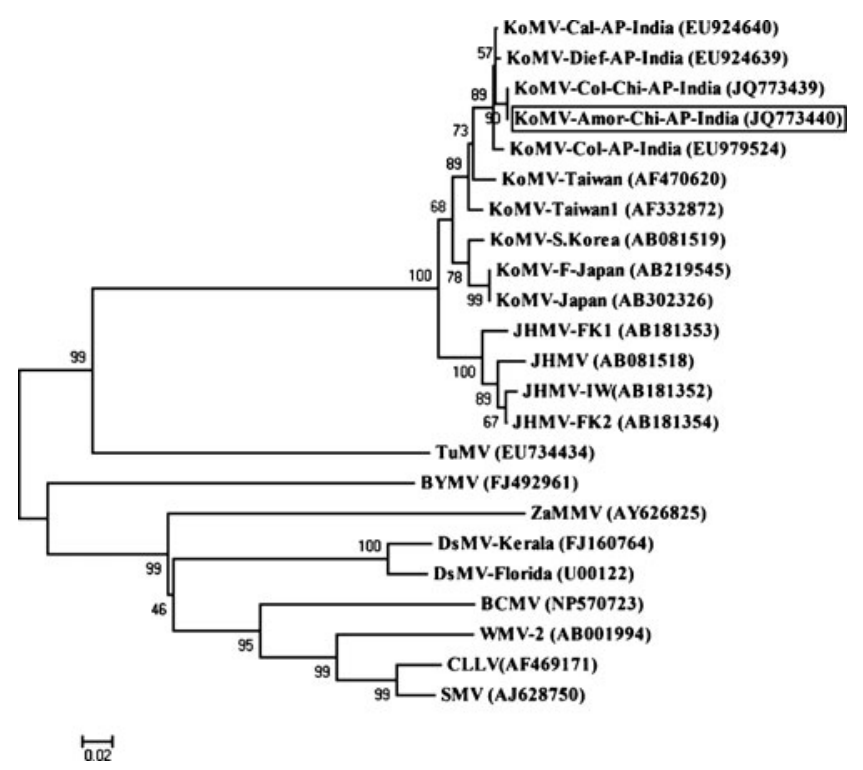

Fig. 3 Neighbor-joining phylogenetic tree showing the relationships of $\mathrm{CP}$ amino acid sequence of KoMV-Amor-Chi-AP isolate with other potyviruses infecting aroid crops. The phylogenetic tree was constructed using MEGA 4.0. The values at the forks indicate the number of trees that this grouping occurred after bootstrapping the data. The scale bar represents a genetic distance of 0.02 . Virus acronyms: KoMV - Konjac mosaic virus, JHMV - Japanese hornwort mosaic virus, TuMV - Turnip mosaic virus, BYMV- Bean yellow mosaic virus, DsMV - Dasheen mosaic virus, ZaMMV - Zantedeschia mild mosaic virus, BCMV- Bean common mosaic virus, WMV-2 Watermelon mosaic virus 2, CLLV-Calla lily latent virus, SMV-Soybean mosaic virus 


\section{References}

Adams MJ, Antoniw JF, Fauquet C (2005) Molecular criteria for genus and species discrimination with in the family Potyvirdae. Arch Virol 150:459-479

Babu B, Hedge V, Makeshkumar T, Jeeva ML (2012) Rapid and sensitive detection of potyvirus infecting tropical tuber crops using genus specific primers and probes. Afr J Biotechnol 11:1023-1027

Clark MF, Bar-Joseph M (1984) Enzyme immunosorbent assays in plant virology. In: Maramorosch K, Koprowski H (eds) Methods in virology, vol 7. Academic, New York, pp 51-85

Kwon SB, Ha JH, Yoon JY, Ryu KH (2002) Zantedeschia mosaic virus causing leaf mosaic symptom in calla lily is a new potyvirus. Arch Virol 147:2281-2289

Nishiguchi M, Yamasaki S, Lu XZ, Shimoyama A, Hanada K, Sonoda S, Shimon M, Sakai J, Mikoshiba Y, Fujisawa I (2006) Konjak mosaic virus: the complete nucleotide sequences of the genomic RNA and its comparision with other potyviruses. Arch Virol 151:1643-1650

Nolasco G, de Blas C, Torres V, Ponz F (1993) A method combining immuno-capture and PCR amplification in a microtitre plate for the detection of plant viruses and subviral pathogens. J Virol Methods 45:201-218

Padmavathi M (2012) Molecular characterization of potyvirus isolates naturally associated with infections on aroid tuber crops and foliage ornamental plants in Andhra Pradesh, India, and development of diagnostics for their detection. Ph.D. thesis. Sri Venkateswara University, Tirupati, Andhra Pradesh, India

Padmavathi M, Srinivas KP, Subba Reddy CV, Ramesh B, Navodayam K, Krishnaprasadji J, Babu Ratan P, Sreenivasulu P (2011) Konjac mosaic virus naturally infecting three aroid plant species in Andhra Pradesh, India. J Phytopathol 159:133-135

Pandit MK, Nath PS, Mukhopadhyay S, Devonshire BJ, Jones P (2001) First report of Dasheen mosaic virus in elephant foot yam in India. Plant Pathol 50:802

Ravi V, Ravindran CS, Suja G (2009) Growth and productivity of elephant foot yam (Amorphophallus paeoniifolius) (Dennst. Nicolson): an overview. J Root Crops 35:131-142

Shimoyama J, Kameya-Iwaki M, Hanada K, Gunji T (1992) Konjac mosaic virus, a new potyvirus infecting konjac, Amorphophallus konjac. Ann Phytopathol Soc Jpn 58:706-712 